\title{
永久気管孔作製の新しい試み
}

\author{
*辺土名 仁, 竹生田勝次, 石川 紀彦 \\ **西嶌 渡, 寺邑 公子 \\ ****野崎 幹弘
}

\section{A New Surgical Method for the Creation of a Permanent Tracheostoma}

\author{
Hitoshi Hentona, M.D., Shoji Takoda, M.D. and Norihiko Ishikawa, M.D. \\ Department of Otolaryngology, Saitama Cancer Center, Saitama \\ Wataru Nishijima, M.D. and Kimiko Teramura, M.D. \\ Department of Otolaryngology, Tokyo Medical and Dental University, Tokyo \\ Motohiro Nozaki, M.D. \\ Department of Plastic Surgery, Tokyo Women's Medical College, Tokyo
}

\begin{abstract}
Stenosis of a permanent tracheostoma may be caused by excessive scar tissues, keloid formation, excessive fatty tissues, defective tracheal rings or recurrent tumor. It was also assumed that high tension at the site of through-and-through sutures may cause stenosis. Based on the above concept, a new surgical method was devised to avoid excessive tension at the stomal margin and to prevent the invasion of fatty tissues to the site of sutures. The new methoddenuded flap tracheostomy — was applied to 13 cases following laryngectomy and satisfactory results were obtained.
\end{abstract}

Key words : denuded flap, tracheostoma

\section{I はじめに}

喉頭全摘後の永久気管孔には時々狭窄がみら れる。Montgomery はその原因を以下のように 述べている。

1）感染や㾇孔による過剩洀痕組織

2）ケロイド

3）気管孔周囲の過㮃な脂肪組織

4）気管輪の欠損

5）、気管孔周囲の再発

しかし上記原因の相当しない狭窄例も少なくな い。そこでわれわれは皮膚気管吻合部の過剩張

*埼玉県立がんセンタ一耳鼻咽喉科

**東京医科歯科大学医学部耳鼻咽喉科

***東京女子医科大学形成外科
力も狭窄の原因になるのではないかと考光，永 久気管孔作製時にひとつの工夫を試みてきた。 これまで喉頭癌を中心とした13例にこの新しい 作製法を用い，好結果を得たのでここに紹介す る。

\section{II 手 術方法}

1. 皮膚切開はU字とする（図 1)。喉摘後, 気管孔周囲や皮弁の過剩脂肪組織を除去する。

2. 皮弁の下端部に気管孔の大きさに合せて 半円形の表皮剝離除去部を作製する（図 2 )。 このとき表皮は可能なかぎり均一な厚さで除去 する。また表皮剝離部上端から数 $\mathrm{mm}$ の幅で表 皮の遊離端を作製する。これは気管膜様部の上 


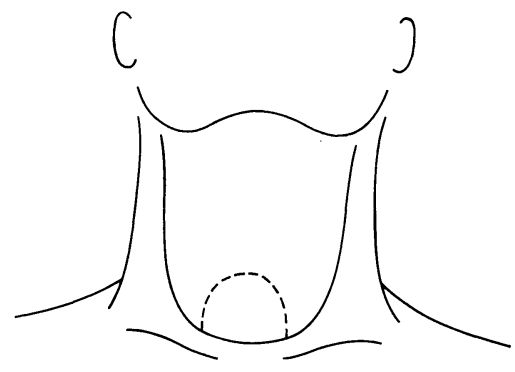

図 1 皮膚切開はU字とする。

破線より下方は表皮剝離部となる。

端を表皮で被覆するのに用いる。

3. 気管を周囲組織より剝離し，その断端を 斜めに切断した後, 皮弁の表皮剝離部を気管膜 様部に裏打ちする（図 3 )。裏打ち部は数本の 絹系にて縫合し, 膜様部上端は皮弁表皮の遊離 端で被覆した後皮弁とナイロン系で縫合する。 他方, 気管軟骨部と胸骨窩の皮膚はナイロン糸 にて端々吻合を行なら。

4. 術後は原則的に気管カニューレを装着す るが，血液の気管内流入を防ぐのが目的であ る。本術式自体にカニューレ装着の必要性は認 めない。

本術式は以上の手順で行ならが，その適応や 応用について述べてみる。本術式は喉頭腫瘍の みならず，下咽頭腫瘍（たと究ば咽頭・喉頭・ 頸部食道摘出術）にも使用できる。また片側あ るいは両側の頸部廓清術を同時に施行しても支 障はない。気管切開は必ずしも必要としない。 皮膚切開は正中切開を用いてもよいが，この場 合には気管孔作成の段階で切開部下端にV字の 補助切開を加える必要がある（図 4)。
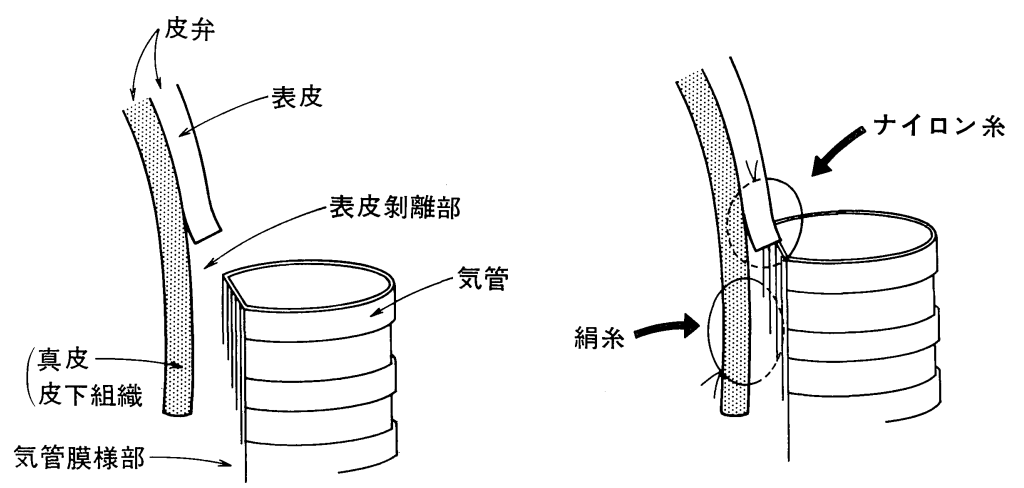

図 3 表皮剥離部を気管膜様部に裏打らする。 


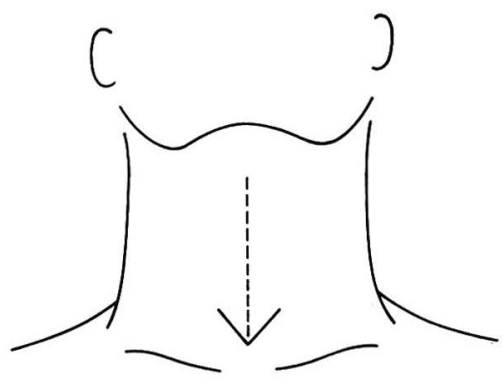

図 4 正中切開では切開線下端にV字の 補助切開を加える。

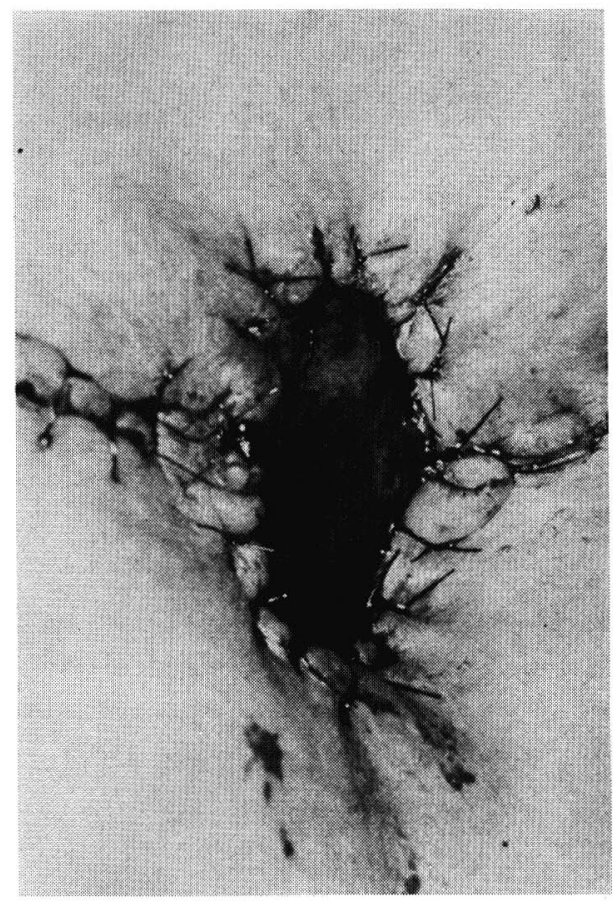

図 5 完成した気管孔。

が確認できる。吻合部から下方の膜様部粘膜に びらんを生じているが，これは本症例が約 1 カ 月半の長期にわたり人工呼吸器を装着していた ためと考兄られる。皮弁の表皮剥離部は膜様部 飞生着して和り, びらん部以外は炎症細胞の浸 潤も少ない。脂肪組織の吻合部への侵入が，真 皮によって妨げられているのが観察される。

\section{IV 考 按}

喉頭全摘出後の永久気管孔の狭窄は術後早期 に出現する場合もあるし，数年経って後みられ ることもある。その狭窄を防ぐため，諸家によ

表 1

\begin{tabular}{|c|c|c|c|c|c|}
\hline 症例 & 性 & 病 名 & 観察期間 & 狭 窄 & 経 過 \\
\hline 1 & 男 & 喉 頭 癌 & 18力月 & - & 生存 \\
\hline 2 & 男 & 喉 頭 癌 & 16力月 & - & 生存 \\
\hline 3 & 男 & 喉 頭 癌 & 16 力月 & - & 生存 \\
\hline 4 & 男 & 喉 頭 癌 & 16 力月 & - & 生存 \\
\hline 5 & 男 & 喉 頭 癌 & 15 力月 & - & 生存 \\
\hline 6 & 女 & 甲状腺癌 & 13カ月 & - & 生存 \\
\hline 7 & 男 & 喉頭 癌 & 13力月 & - & 生存 \\
\hline 8 & 女 & 下咽頭癌 & 2 力月 & - & 死亡 \\
\hline 9 & 男 & 下咽頭癌 & 12 力月 & - & 生存 \\
\hline 10 & 男 & 喉頭癌 & 11 力月 & - & 生存 \\
\hline 11 & 男 & 喉 頭 癌 & 11 カ月 & - & 生存 \\
\hline 12 & 男 & 喉 頭 癌 & 10カ月 & - & 生存 \\
\hline 13 & 男 & 下咽頭癌 & 9 カ月 & - & 生存 \\
\hline
\end{tabular}

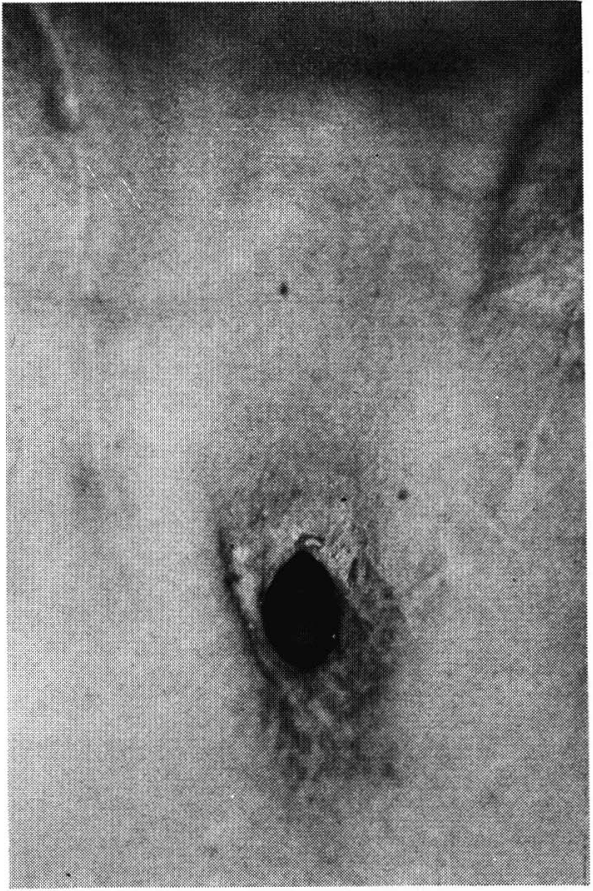

図 6 18力月後の気管孔。

って種々の工夫がなされてきた。

Montgomery (1973) ${ }^{2)}$ は気管孔作製にあた り，(1)気管断端を斜めに切断する，(2)気管断端 の長さに合せるように，皮切部下端を円形ある いは半円形に皮膚切除する，(3)端々吻合によっ て気管断端を完全に皮膚で被う，と述べてい 


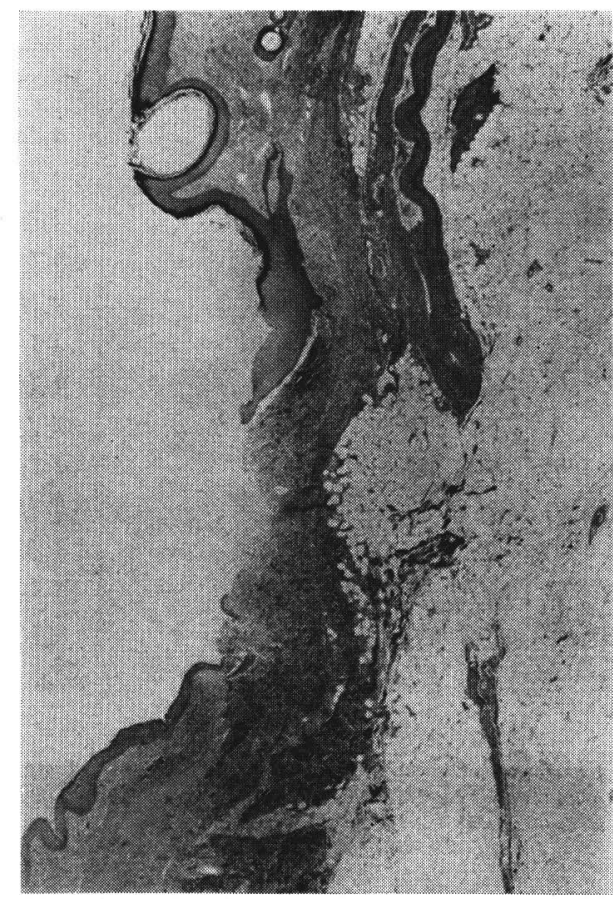

図 7 上方は皮弁。中夫部は裏打ち部で上皮 の脱落をみる。下方は膜様部

る。Hartwell (1967) ${ }^{3)}$ は気管膜様部にV字の切 除を加光, その切除部位に楔状の皮弁下端を挿 入する方法を試みた。Isshiki (1980) ${ }^{4)}$ の試みも この方法に類似する。その特徴は, 皮弁の一部 を気管壁に挿入乙気管孔辺縁の長さを延長する ことにある。これは Montgomery の試み, 気 管断端を斜めに切断して気管孔辺縁を長くする 工夫，をさらに改善した方法といえる。天津と Jatho ら (1976) ${ }^{5)}$ は気管前面を気管切開孔より 上部で正中断し，その気管輪を左右に観音開き にする方法を試みている。そのため気管皮膚 吻合部と本来の気管輪との間に距離が保たれ, 気管孔周囲の皮膚縁はかなり長くなる。Montgomery は皮切部下端の皮膚を円形に切除する ことで気管孔の皮膚円周を長くしたが，過剩に 切除すると気管皮膚吻合部の張力は大きくな る。しかし天津ら ${ }^{5)}$ のこの方法は気管輪を左右 に観音開きにし，気管輪辺縁を側方に延長する ことでその欠点を補っている。Mumma(1951)6) は tantalum ring を気管孔の皮下に挿入する方 法を試みている。金属の防壁により狭窄を予防
するのが目的であったが，結局狭窄を予防でき ず以来用いられていない。

以上のように永久気管孔の作製方法は諸家に よって工夫されてきたが，われわれは気管皮膚 吻合部の張力注目して本術式を考案した。本 術式は図 3 のごとく皮弁を膜様部に裏打ちする ため，気管全体を皮弁によってつりあげること になり，その張力は主に裏打ち部の絹糸にかか る。そのため皮弁表皮一膜様部吻合の張力は減 少し, 吻合部の弛緩や哆開を防ぐと考えられ る。そして過剩張力を減ずるというこの特徴は 特そらく術後早期に起こる狭窄に対して有効で あろらと推察される。また従来用いられてきた 食道前壁の線維膜・筋層で気管をつり上げる方 法は，下咽頭癌などに执いて頸部食道を摘出し た場合には使用できない。しかし本術式はこの ような例に打いても問題はなく, 食道再建部に 影響を与えず気管孔を作製できる。

本術式のもらひとつの特徴として, 吻合部に 脂肪組織が侵入できない，といら点が挙げられ る。皮弁表皮と膜様部断端との吻合部はその下 層に皮弁の厚い結合組織（真皮）を有して抹 り，その真皮は膜様部に沿って尾側へ長く裏打 ちされている。そのため，上り深層に存在する 脂肪組織は真皮に妨げられて表皮膜様部吻合へ 直接侵入ができない。これは脂肪組織による吻 合部への影響を減少させる。従来の端々吻合で は吻合部直下に脂肪組織が存在するため, その 増加によって吻合部は気管内腔側へ突出しやす くなる。しかし著者らの方法は吻合部之脂肪組 織との間に真皮が介在するため, 脂肪組織の気 管内腔に向から力が皮弁と膜様部に 分散され る。それゆ光吻合部局所飞叔壮る圧は減少し， 狭窄も少なくなると推察される。

最後に本術式を “Denuded Flap Tracheostomy”と名付けたい。

\section{$\mathrm{V}$ まめ}

永久気管孔の狭窄で, 吻合部の過㮃張力もそ の原因になるのではないかと考えた。皮弁と気 管との端々吻合ではなく，皮弁の表皮剝離部を 膜様部に裏打ちし吻合部の張力を減じた。本術 式を喉頭癌を中心とした13例に用い好結果を得 た。 
本論文の要旨は第35回日本気管食道科学総会に和い て発表した。

\section{文献}

1) Montgomery, W.W. Stenosis of tracheostoma. Arch. Otolaryngol., $75: 62-65,1962$.

2) Montgomery, W.W.: Surgery of the upper respiratory system, Vol.2, Lea and Febiger, Philadelphia, 1973.

3) Hartwell, S.W.: Construction and care of the end tracheostomy. Am. J. Surg., $113: 498-500$, 1967.
4) Issiki, N.: A simple technique to prevent stenosis of the tracheostoma after total laryngectomy. J. Laryngol. Otol., 94 : 637-642, 1980.

5 ) 天津睦郎 - 他：喉摘後気管孔の新しい形成法, 耳 喉, 48:909-912, 1976.

6) Mumma, C.S. et al. : S. T. E. T., 3) より引用. 別刷請求：干362 埼玉県北足立郡伊奈町大字小 室 818 番地

埼玉県立がんセンター耳鼻咽喉科 辺土名 仁

（投稿受付 1984年 6 月 6 日） 